\title{
Comparison of interannual snowmelt-onset dates with atmospheric conditions
}

\author{
Sheldon D. Drobot, Mark R. Anderson \\ Department of Geosciences, 214 Bessey Hall, University of Nebraska, Lincoln, NE 68588-0340, U.S.A.
}

\begin{abstract}
The snowmelt-onset date represents an important transitional point in the Arctic surface energy balance, when albedo decreases and energy absorption increases rapidly in response to the appearance of liquid water. Interannual variations in snowmelt onset are likely related to large-scale variations in atmospheric circulation, such as described by the Arctic Oscillation $(\mathrm{AO})$. This research therefore examines the relationship between monthly-averaged AO values and mean annual snowmelt-onset dates over Arctic sea ice in 13 regions, from 1979 to 1998. The objective is to statistically relate variations in mean annual regional snowmelt-onset dates to variations in the AO. Additionally, monthly-averaged $500 \mathrm{hPa}$ heights and $2 \mathrm{~m}$ air temperatures are used to illustrate a physical link between snowmelt onset and a positive AO phase. Regression analyses demonstrate that variations in the $\mathrm{AO}$ explain a significant portion of the variations in snowmelt onset in the West Central Arctic, Laptev Sea, East Siberian Sea, Hudson Bay and Baffin Bay. Synoptic analyses suggest earlier (later) than average snowmelt onset occurs where warm (cold) air advection and increased (decreased) cyclonic activity are present.
\end{abstract}

\section{INTRODUGTION}

Snow on sea ice plays an integral role in the Arctic's energy balance, owing to its influence on surface albedo, sensibleand latent-heat exchanges, and because of its considerable spatial and temporal variability. The significance of snow is particularly emphasized during the snowmelt period (Groisman and others, 1994), when the surface albedo drops from values of $>0.8$ for dry snow-covered surfaces, to values of $<0.3$ for wet snow-covered surfaces (Goodison and others, 1999). The change in albedo from a highly reflective surface to a highly absorptive surface is expedited by the temperature-albedo feedback (Curry and others, 1995), where an increase in air temperature enhances surface melt, reducing the spatial coverage of snow, decreasing albedo and in turn leading to greater absorbed energy and warmer air temperatures. Based partly upon this temperaturealbedo feedback, general circulation models typically predict enhanced climate warming in the Arctic (e.g. Maxwell and others, 1998; Gates and others, 1999), highlighting the need to better understand spatial and temporal variations in snowmelt.

Observational studies of passive-microwave-derived snowmelt onset, defined as the point in time when brightness temperatures increase in response to liquid-water inclusions around snow grains, demonstrate that there is significant spatial and temporal variability (Abdalati and Steffen, 1995; Mote and Anderson, 1995; Smith, 1998). A regional assessment (Fig. 1) of the spatial and temporal variability in snowmelt-onset dates from 1979 to 1998 (Anderson and Drobot, 2001) illustrates large variations in the timing of snowmelt onset between regions in a given year, and between years within a given region (Fig. 2). Anderson and Drobot (2001) hypothesize the snowmelt-onset variations are at least partly related to variations in atmospheric conditions. The objec- tive of this paper is therefore to examine how atmospheric variations relate to snowmelt onset. The Arctic Oscillation $(\mathrm{AO})$ is used to represent atmospheric variability, because other studies on atmosphere--sea-ice interactions (e.g. Deser and others, 2000) note sea-ice variations are strongly associated with $\mathrm{AO}$ variations. The AO is defined as a see-saw between anomalously high and low pressure over the Arctic, and is considered the dominant mode of low-frequency atmospheric variability in the Northern Hemisphere (Thompson and Wallace, 1998). Regression analyses are used to statistically associate monthly-averaged $\mathrm{AO}$ values with mean annual regional snowmelt-onset dates. In addition, a

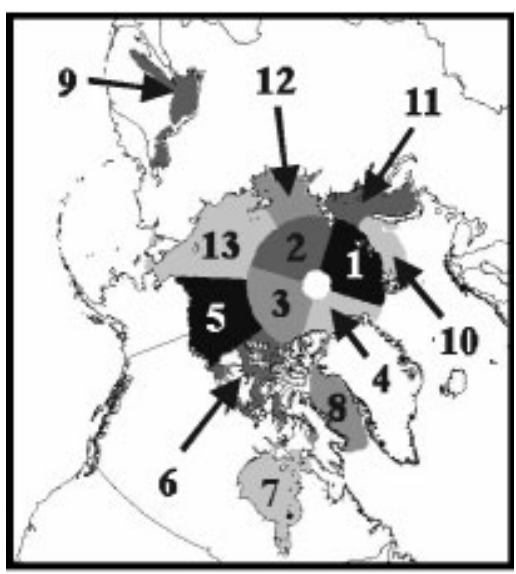

Fig. 1. Regional study sites: 1. East Central Arctic; 2. Mid Central Arctic; 3. West Central Arctic; 4. Lincoln Sea; 5. Beaufort Sea; 6. Canadian Arctic Archipelago; 7. Hudson Bay; 8. Baffin Bay; 9. Sea of Okhotsk; 10. Barents Sea; 11. Kara Sea; 12. Laptev Sea; 13. East Siberian Sea. 


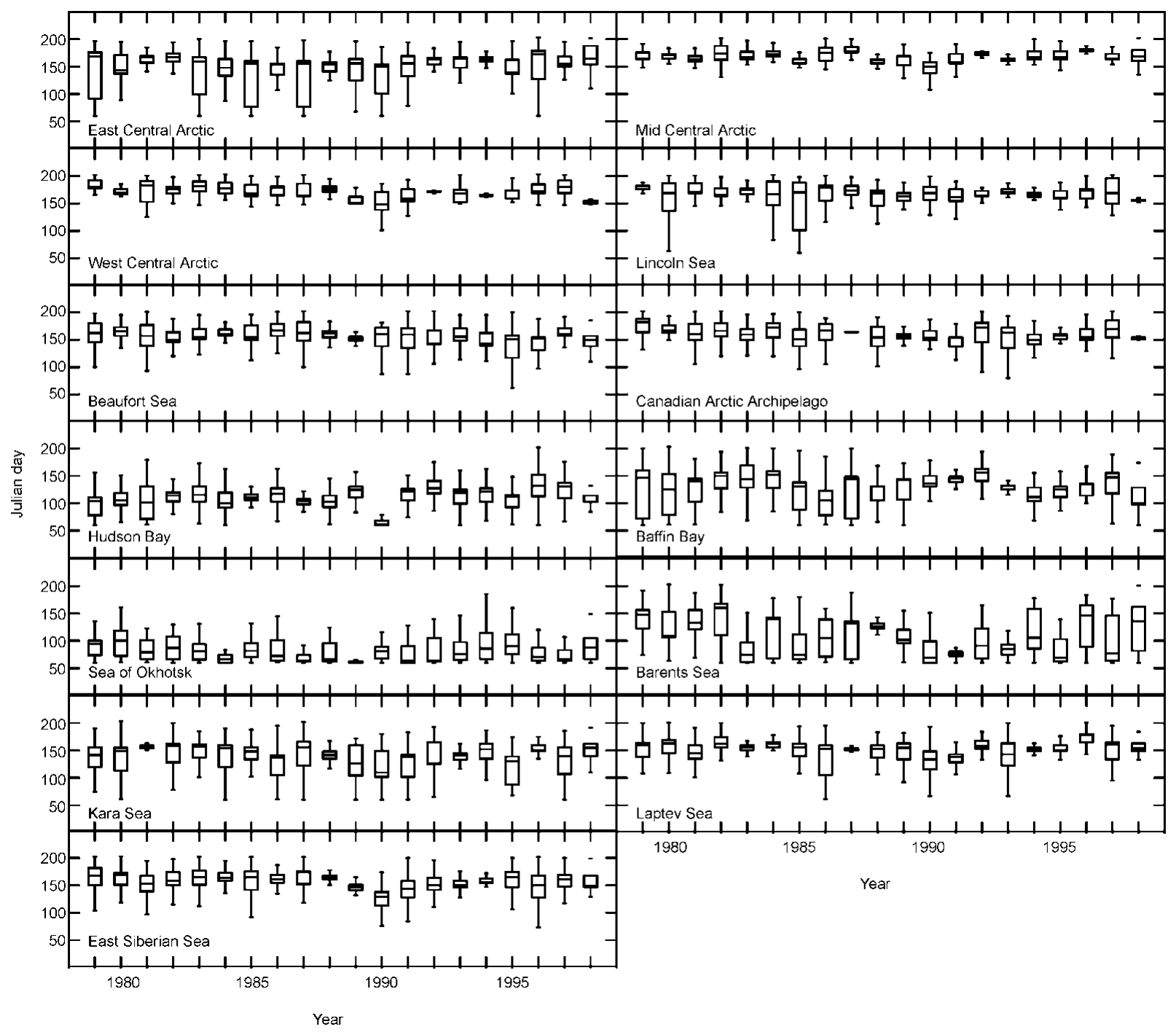

Fig. 2. Temporal variability in median annual melt-onset dates for each region.

case-study in 1990 further defines the relationship between $500 \mathrm{hPa}$ heights, $2 \mathrm{~m}$ air temperatures and snowmelt onset.

\section{DATA}

Snowmelt-onset dates are derived with $25 \mathrm{~km}^{2}$ daily-averaged brightness-temperature data from Scanning Multichannel Microwave Radiometer (SMMR) and Special Sensor Microwave/Imager (SSM/I) radiometers. An improved version of the Anderson (1997) algorithm is used to compute snowmelt onset over first-year and multi-year sea-ice surfaces from 1979 to 1998. The new algorithm, termed the Advanced Horizontal Range algorithm (AHRA), monitors the difference between $18 \mathrm{GHz}$ (SMMR) or $19 \mathrm{GHz}(\mathrm{SMM} / \mathrm{I})$ and $37 \mathrm{GHz}$ horizontal brightness temperatures over a 20 day window. At the snowmelt-onset point, liquid-water inclusions form around snow grains, and the difference between 18 or $19 \mathrm{GHz}$ minus $37 \mathrm{GHz}$ horizontal brightness temperatures changes from being positive to near zero or negative. By monitoring the 20 day window for signs of a consistent change in the 18 or $19 \mathrm{GHz}-37 \mathrm{GHz}$ brightness temperature, the occurrence and variability in snowmelt onset are monitored. Additional details on the AHRA are provided in a companion paper (Anderson and Drobot, 2001) as well as Drobot (2000).
Although the AHRA has been verified for use over first-year and multi-year sea-ice surfaces, anomalous snowmelt-onset dates, due to pixel averaging, sensor errors, polynyas, etc., may still be present in the snowmelt-onset dataset. In most cases, however, this should not affect the overall results.

The snowmelt dates are subsequently stratified into the same 13 regions as Anderson and Drobot (2001) in order to examine the regional associations between snowmelt onset and the AO. Note that the regions north of $80^{\circ} \mathrm{N}$ closely resemble regions developed by Smith (1998), but they are shifted $45^{\circ}$ in this study from the work of Smith (1998) in order to keep snowmelt-onset dates in the Lincoln Sea in one region.

Atmospheric data consist of monthly-averaged $\mathrm{AO}$ values, $500 \mathrm{hPa}$ heights and $2 \mathrm{~m}$ air temperatures, all derived from U.S. National Centers for Environmental Prediction/ National Center for Atmospheric Research (NCEP/NCAR) re-analysis data. The re-analysis data provide a consistent source for atmospheric data, because re-analysis data are based on a static data-assimilation scheme, quality control is superior to first-order stations, the data analysis is global in extent and more observations are used (Kalnay and others, 1996). The monthly-averaged $\mathrm{AO}$ values were acquired from the Joint Institute for the Study of Atmosphere and Ocean (JISAO) at the University of Washington, while the $500 \mathrm{hPa}$ height and $2 \mathrm{~m}$ air-temperature data were collected from 
Table 1. Monthly averaged AO values, 1979-98

\begin{tabular}{lrrrrr}
\hline Year & Feb. & Mar. & Apr. & May & June \\
\hline 1979 & -0.51 & -0.75 & -1.41 & -0.20 & 0.70 \\
1980 & -0.11 & -1.34 & -0.30 & -1.04 & 0.52 \\
1981 & 0.19 & -1.44 & 0.54 & 0.33 & -0.51 \\
1982 & 1.28 & 1.06 & 1.35 & -0.31 & -1.16 \\
1983 & -0.87 & -0.13 & -0.87 & -0.48 & 0.29 \\
1984 & 0.20 & -2.03 & -0.29 & 0.49 & -0.07 \\
1985 & -1.50 & 0.57 & 0.45 & -0.39 & -0.48 \\
1986 & -2.03 & 2.37 & -0.01 & 0.35 & 0.59 \\
1987 & -1.03 & -1.54 & 0.51 & 0.35 & -0.73 \\
1988 & -0.69 & -0.22 & -0.47 & -0.76 & 0.12 \\
1989 & 3.46 & 1.54 & -0.30 & 0.81 & 0.25 \\
1990 & 3.28 & 3.31 & 1.86 & 1.18 & 0.20 \\
1991 & -0.13 & -0.50 & 0.57 & 0.58 & -0.29 \\
1992 & 1.68 & 1.19 & -0.66 & 1.37 & -0.26 \\
1993 & 1.05 & 1.15 & -0.26 & -1.45 & -0.61 \\
1994 & -0.51 & 1.82 & 0.16 & 0.03 & 1.38 \\
1995 & 1.70 & 0.37 & -0.97 & -0.82 & -0.09 \\
1996 & 0.71 & -1.24 & -1.38 & -0.30 & 0.32 \\
1997 & 2.42 & 1.11 & 0.50 & -0.93 & -0.80 \\
1998 & 0.65 & -0.02 & 0.50 & -0.90 & -0.25 \\
& & & & & \\
\hline
\end{tabular}

NCAR. Atmospheric data were analyzed only for the months February-June, since most snowmelt occurs during this period (Smith, 1998; Drobot, 2000).

\section{METHODS}

A two-step analytical approach is used to demonstrate $\mathrm{AO}-$ snowmelt-onset relationships. Regression analyses between the monthly-averaged $\mathrm{AO}$ values and mean annual regional snowmelt-onset dates highlight statistical associations between the $\mathrm{AO}$ and snowmelt onset. While these statistical analyses are useful in determining regional relationships between the $\mathrm{AO}$ and snowmelt onset, the statistical associations cannot explain fully how the AO influences snowmelt onset. Synoptic atmospheric conditions are therefore examined during a pronounced positive $\mathrm{AO}$ phase to illustrate how atmospheric manifestations of the AO, namely, $500 \mathrm{hPa}$ heights and $2 \mathrm{~m}$ air temperatures, influence snowmelt onset. To facilitate synoptic analysis, the atmospheric data are compared with snowmelt-onset anomalies extending into the middle of the following month. For example, atmospheric conditions in April are compared to the melt anomalies up to 15 May. The rationale for this approach is that the low-frequency features of the $500 \mathrm{hPa}$ heights and $2 \mathrm{~m}$ air temperatures from one month blend into the beginning of the following month. Therefore, the atmospheric conditions in one month will influence snowmelt onset in the beginning of the next month.

\section{STATISTIGAL LINKS BETWEEN THE AO AND SNOW- MELT ONSET}

An examination of monthly-averaged $\mathrm{AO}$ values (Table 1) demonstrates that annual and monthly variations in the strength and phase of the AO are common. In some years, such as 1990, a pronounced positive phase dominates from February through June, while in others, such as 1979 and 1980 , a strong negative phase is present in all but one month. However, in most years a mixture of positive and negative phases typically exists.
Table 2. Per cent variation of mean annual snowmelt-onset dates that are explained by variations in monthly-averaged $A O$ values. Statistically significant relationships $(\alpha=0.05)$ are represented by bold text

\begin{tabular}{lccccc}
\hline Region & \multicolumn{5}{c}{$r^{2}$ values } \\
& Feb. & Mar. & Apr. & May & fune \\
& & & & & \\
\hline 1. East Central Arctic & $0.00^{\dagger}$ & $0.01^{*}$ & $0.01^{*}$ & $0.09^{*}$ & $0.00^{*}$ \\
2. Mid Central Arctic & $0.14^{*}$ & $0.19^{*}$ & $0.18^{*}$ & $0.04^{*}$ & $0.00^{*}$ \\
3. West Central Arctic & $\mathbf{0 . 2 2}^{*}$ & $\mathbf{0 . 2 1}^{*}$ & $0.19^{*}$ & $0.05^{*}$ & $0.00^{*}$ \\
4. Lincoln Sea & $0.04^{\dagger}$ & $0.00^{\dagger}$ & $0.04^{*}$ & $0.01^{\dagger}$ & $0.03^{\dagger}$ \\
5. Beaufort Sea & $0.19^{*}$ & $0.01^{*}$ & $0.04^{\dagger}$ & $0.00^{*}$ & $0.01^{*}$ \\
6. Canadian Arctic Archipelago & $0.00^{\dagger}$ & $0.08^{*}$ & $0.04^{*}$ & $0.00^{\dagger}$ & $0.01^{*}$ \\
7. Hudson Bay & $0.01^{*}$ & $0.02^{*}$ & $\mathbf{0 . 2 6}^{*}$ & $0.03^{*}$ & $0.00^{*}$ \\
8. Baffin Bay & $\mathbf{0 . 2 4}^{\dagger}$ & $0.00^{*}$ & $0.00^{\dagger}$ & $0.13^{\dagger}$ & $0.13^{*}$ \\
9. Sea of Okhostk & $0.08^{*}$ & $0.00^{\dagger}$ & $0.01^{*}$ & $0.18^{*}$ & $0.06^{\dagger}$ \\
10. Barents Sea & $0.06^{*}$ & $0.18^{*}$ & $0.02^{*}$ & $0.05^{*}$ & $0.01^{\dagger}$ \\
11. Kara Sea & $0.14^{*}$ & $0.18^{*}$ & $0.00^{\dagger}$ & $0.04^{*}$ & $0.03^{*}$ \\
12. Laptev Sea & $0.00^{\dagger}$ & $\mathbf{0 . 2 0}^{*}$ & $0.19^{*}$ & $0.11^{*}$ & $0.01^{*}$ \\
13. East Siberian Sea & $\mathbf{0 . 4 1}^{*}$ & $\mathbf{0 . 2 7}^{*}$ & $0.14^{*}$ & $\mathbf{0 . 2 5}^{*}$ & $0.00^{*}$
\end{tabular}

* indicates positive (negative) AO phases associated with earlier (later) than average snowmelt onset.

$\dagger$ indicates positive (negative) AO phases associated with later (earlier) than average snowmelt onset.
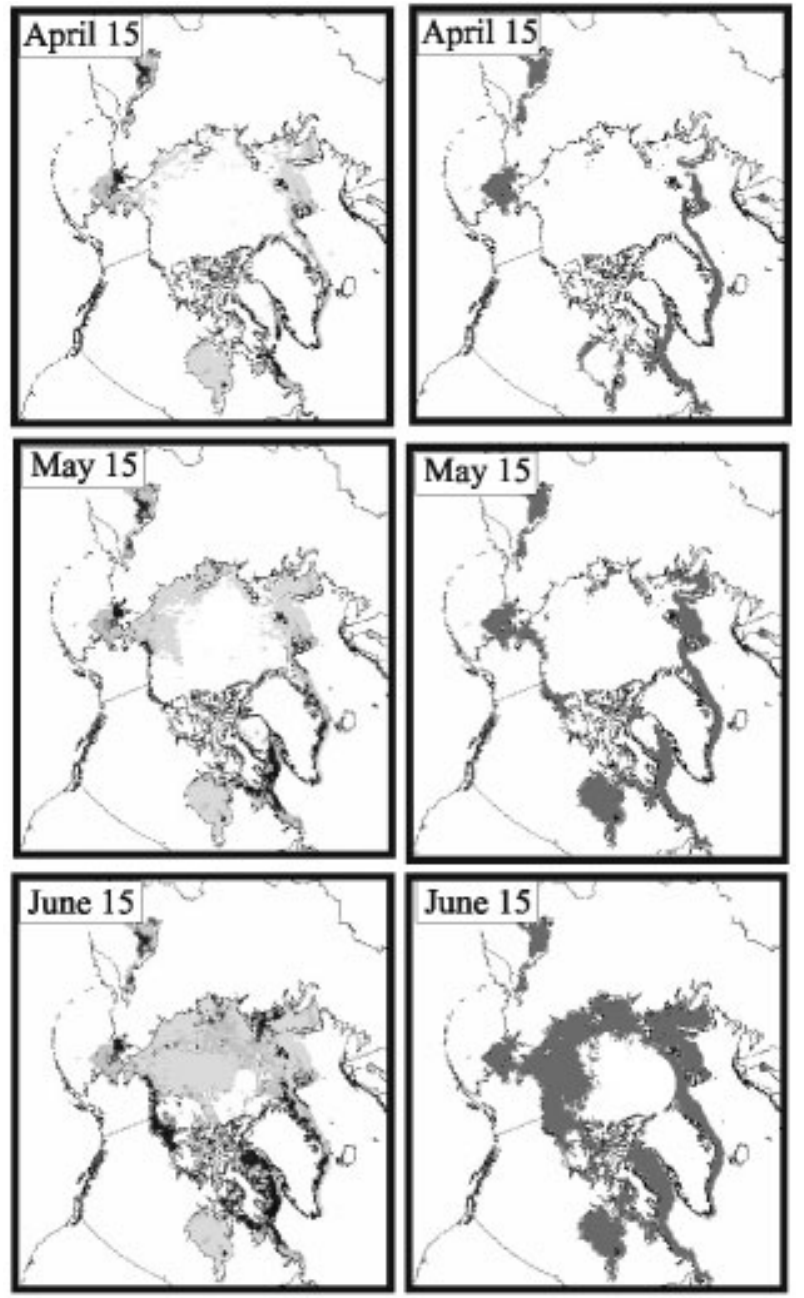

Melt Anomaly (days)

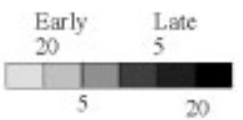

Shaded pixels indicate regions where melt onset typically oceurs by mid-month.

Fig. 3. Snowmelt anomalies in 1990 (left) compared with mean snowmelt coverage from 1979 to 1998 (right). 

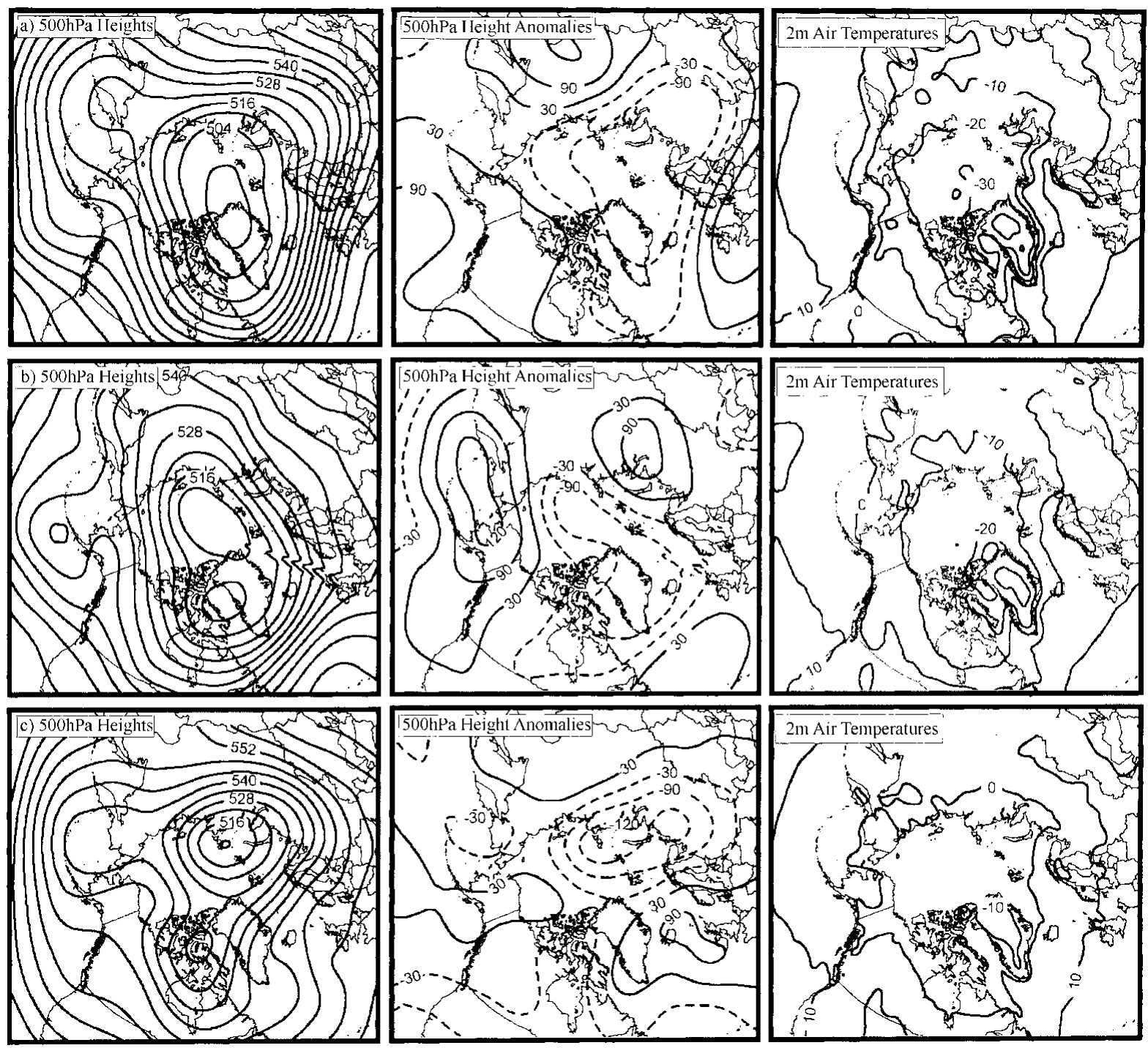

Fig. 4. 500 hPa heights and $2 \mathrm{~m}$ air temperatures for (a) March, (b) April and (c) May 1990.

Since phase changes in the AO are linked to large atmospheric variations in near-surface air temperatures and sealevel pressure across the Arctic (Thompson and Wallace, 1998), it is not surprising that monthly-averaged $\mathrm{AO}$ values (Table 1) are significantly related to mean annual snowmeltonset dates in several regions (Table 2). Variations in February $\mathrm{AO}$ values explain a significant portion of the variations in mean annual snowmelt-onset dates in the West Central Arctic, Baffin Bay and East Siberian Sea. Variations in March AO values also explain a significant portion of the variations in mean annual snowmelt-onset dates in the West Central Arctic, Laptev Sea and East Siberian Sea. Variations in April AO values explain a significant portion of the variations in mean annual snowmelt-onset dates in Hudson Bay, while variations in May $\mathrm{AO}$ values explain a significant portion of the variations in mean annual snowmelt-onset dates in the East Siberian Sea. The significant relationships imply positive (negative) phases of the $\mathrm{AO}$ are associated with earlier (later) snowmelt onset in the West Central Arctic, Laptev Sea, East Siberian Sea and Hudson Bay, and later (earlier) snowmelt onset in Baffin Bay. These results are consistent with the findings of Thompson and Wallace (1998), who noted positive AO phases were related to enhanced surface warming in western Russia and cooling in southern Greenland and
Labrador. The regression analyses between February and March AO values and mean annual snowmelt-onset dates in the West Central Arctic also suggest there are lag relationships between the atmosphere and snowmelt onset, since snowmelt onset does not typically occur in the West Central Arctic until May or June (Anderson and Drobot, 2001). While this implies some sort of complex relationship between the atmosphere and snowmelt, it is likely that the reduction in significant associations in the latter months is actually due to increased variability in atmospheric conditions as the spring progresses. Serreze and others (1993) note shortwave synoptic activity in the Arctic increases in summer, and thus dominant low-frequency atmospheric patterns such as the AO become weaker. This would in turn make it more difficult to extract significant relationships between the $\mathrm{AO}$ and snowmelt onset in the latter months.

\section{SYNOPTIC ANALYSIS FOR 1990}

To better understand why positive (negative) AO phases correspond with earlier (later) than average snowmelt onset in the West Central Arctic, Hudson Bay, Laptev Sea and East Siberian Sea, and later (earlier) than average snowmelt onset in Baffin Bay, snowmelt onset and atmospheric conditions 
are examined during the positive AO phase of 1990. Generally, snowmelt occurred earlier than average over most of the western Arctic in 1990, and later than average over the Beaufort Sea, the Canadian Arctic Archipelago and Baffin Bay (Fig. 3). The aerial coverage of snowmelt by mid-month was also greater in comparison to average melt conditions over much of the western Arctic. Greater aerial coverage of snowmelt is especially evident prior to 15 May in the East Siberian Sea, and also for snowmelt occurring prior to 15 June in the Arctic Ocean. Conversely, the aerial coverage of snowmelt by mid-month was diminished over the Beaufort Sea, the Canadian Arctic Archipelago and Baffin Bay, in comparison with average snowmelt conditions (Fig. 3).

An examination of monthly averaged $500 \mathrm{hPa}$ heights and $2 \mathrm{~m}$ air temperatures reveals several possible mechanisms by which the atmosphere influences snowmelt onset in 1990. Consistent with positive $\mathrm{AO}$ phases, $500 \mathrm{hPa}$ heights are below average in the central Arctic during March (Fig. 4). The resulting flow pattern suggests that thermal advection, cloud cover and atmospheric moisture content, the latter two associated with cyclonic shortwave disturbances, are contributing factors in influencing snowmelt. For instance, thermal advection of near $0^{\circ} \mathrm{C}$ air provides a mechanism for the abnormally early snowmelt between Svalbard and Novaya Zemlya, and in the Kara Sea. In comparison, thermal advection of cold air from the Canadian Arctic Archipelago into Baffin Bay could explain the lack of snowmelt in the Baffin Bay region by mid-April. The $500 \mathrm{hPa}$ flow pattern also implies increased cyclonic activity could be present in the Kara Sea area, since the $500 \mathrm{hPa}$ level is often considered a steering level for shortwave disturbances. Therefore, cyclonic systems traveling along the $500 \mathrm{hPa}$ flow pattern would preferentially travel into the Kara Sea region, bringing increased cloudiness, enhancing the surface longwave radiation flux and possibly increasing atmospheric moisture. Since an increase in the surface longwave radiation flux is known to cause snowmelt (Crane and Anderson, 1994), the presence of increased cyclonic activity could account for the abnormally early observed snowmelt.

A slight shift in the April $500 \mathrm{hPa}$ flow pattern is a result of abnormally high heights near the Aleutian Low and abnormally low heights near the central Arctic Ocean, Barents and Kara Seas and Hudson and Baffin Bays (Fig. 4). The corresponding $500 \mathrm{hPa}$ flow pattern veers north after reaching western Russia, and instead of traveling around the Aleutian Low, airflow traverses the Russian coastline into the East Siberian Sea. Abnormally warm air $\left(5^{\circ} \mathrm{C}\right.$ above normal $)$ and cyclonic systems subsequently flow into the Laptev and East Siberian Seas, where earlier than average melt covers a greater area than is typically expected (Fig. 3). Conversely, there is little snowmelt in Baffin Bay, and what does melt is abnormally late. The $500 \mathrm{hPa}$ flow pattern near Baffin Bay is similar to March, when cold air advection from the central Arctic into Baffin Bay could delay snowmelt.

In May, the $500 \mathrm{hPa}$ flow pattern remains similar to April (Fig. 4), with the flow pattern favoring advection of warm air and increased cyclonic activity over the Laptev Sea, the East Siberian Sea and portions of the Arctic Ocean, where abnormally early melt (Fig. 3) covers a much greater area than would normally be expected in these regions. In contrast, melt in the Beaufort Sea is delayed (Fig. 3), possibly because the $500 \mathrm{hPa}$ flow pattern favors advection of cool Arctic air over the Beaufort Sea.

Based on the synoptic analysis for 1990, a reasonable hypothesis is that early snowmelt onset occurs when abnor- mally warm air temperatures and/or increased cyclonic activity are present, and delayed snowmelt onset occurs when abnormally cool air and/or decreased cyclonic activity exists. These results are consistent with other papers on atmospheresea-ice interactions, which noted atmospheric circulation patterns exert a strong influence over sea-ice conditions (e.g. Serreze and others, 1995; Maslanik and others, 1996, 1999). Moreover, Maslanik and others (1996) refer specifically to how increased cyclonic activity in the central Arctic may be responsible for decreases in sea-ice extent, especially in the Siberian sector. The increase in cyclonic activity may also account for some of the statistically significant trends towards earlier snowmelt onset observed in the West Central Arctic (Anderson and Drobot, 2001). Additional research into atmosphere--snowmelt relationships will be valuable in determining the atmospheric influence on snowmelt, and in predicting how future changes in atmospheric circulation might alter snowmelt onset over Arctic sea ice.

\section{SUMMARY}

Utilizing passive-microwave-derived snowmelt-onset dates, and monthly-averaged $\mathrm{AO}$ values, $500 \mathrm{hPa}$ heights and $2 \mathrm{~m}$ air temperatures, atmosphere--snowmelt-onset relationships were examined. Regression analyses showed variations in the AO explained a significant amount of the variation in mean annual snowmelt-onset dates in the West Central Arctic, Laptev Sea, East Siberian Sea, Hudson Bay and Baffin Bay. Positive (negative) phases of the AO were related to earlier (later) than average snowmelt onset in the West Central Arctic, Laptev Sea, East Siberian Sea and Hudson Bay, and later (earlier) snowmelt onset in Baffin Bay.

An examination of monthly-averaged $500 \mathrm{hPa}$ heights and $2 \mathrm{~m}$ air temperatures for 1990 provided plausible explanations behind the observed snowmelt onset for 1990 . Earlier (later) than average melt onset occurred where the $500 \mathrm{hPa}$ flow pattern favored enhanced (diminished) warm-air advection and/or increased (decreased) cyclonic activity. The results show low-frequency atmospheric variations play an important role in defining the observed variations in snowmelt onset. Further analysis of low-frequency variations and snowmelt onset should provide a better understanding of atmosphere--snowmelt-onset interactions, which can then be applied to understand better the impact of projected climate warming on future snowmelt conditions.

\section{ACKNOWLEDGEMENTS}

This work was supported by NASA grant NGT5-30175. Brightness-temperature data were obtained from the National Snow and Ice Data Center in Boulder, CO. Monthlyaveraged $\mathrm{AO}$ values were acquired from the JISAO. The comments of reviewers are also gratefully acknowledged.

\section{REFERENCES}

Abdalati, W. and K. Steffen. 1995. Passive microwave-derived snow melt regions on the Greenland ice sheet. Geophys. Res. Lett., 22(7), 787-790.

Anderson, M. R. 1997. Determination of a melt-onset date for Arctic sea-ice regions using passive-microwave data. Ann. Glaciol., 25, 382-387.

Anderson, M. R. and S. Drobot. 2001. Spatial and temporal variability in snowmelt onset over Arctic sea ice. Ann. Glaciol., 33 (see paper in this volume).

Crane, R. G. and M. R. Anderson. 1994. Springtime microwave emissivity changes in the southern Kara Sea. 7. Geophys. Res., 99(C7), 14,303-14,309. 
Curry, J. A., J. L. Schramm and E. E. Ebert. 1995. Sea ice-albedo climate feedback mechanism. 7. Climate, 8(2), 240-247.

Deser, G., J. E. Walsh and M. S. Timlin. 2000. Arctic sea ice variability in the context of recent atmospheric circulation trends. F. Climate, 13(3), 617-633.

Drobot, S. D. 2000. Spatial and temporal variability in snowmelt onset over Arctic sea ice and associated atmospheric conditions. (Ph.D. thesis, University of Nebraska-Lincoln.)

Gates, W. L. and 15 others. 1999. An overview of the results of the Atmospheric Model Intercomparison Project (AMIP-I). Bull. Am. Meteorol. Soc., 80, 29-55.

Goodison, B. E. and 20 others. 1999. Cryospheric systems. In Greenstone, R. and M. D. King, eds. EOS science plan: executive summary. Washington, DC, U.S. National Aeronautics and Space Administration, 261-307.

Groisman, P.Ya., T. R. Karl and R.W. Knight. 1994. Observed impact of snow cover on the heat balance and the rise of continental spring temperatures. Science, 263(5144), 198-200.

Kalnay, E. and 21 others. 1996. The NCEP/NCAR 40-year reanalysis project. Bull. Am. Meteorol. Soc., 77(3), 437-471.

Maslanik, J. A., M. C. Serreze and R. G. Barry. 1996. Recent decreases in Arctic summer ice cover and linkages to atmospheric circulation anomalies. Geophys. Res. Lett., 23(13), 1677-1680.

Maslanik, J. A., M. C. Serreze and T. A. Agnew. 1999. On the record reduction in western Arctic sea-ice cover in 1998: characteristics and relationships to atmospheric circulation. Geophys. Res. Lett., 26(13), 1905-1908.

Maxwell, B. and 36 others. 1998. The Arctic and Antarctic. In Watson, R. T., M. C. Zinyowera and R. H. Moss, eds. The regional impacts of climate change: an assessment of vulnerability. Cambridge, etc., Cambridge University Press. Intergovernmental Panel on Climate Change (IPCG), 87-148.

Mote, T. L. and M. R. Anderson. 1995. Variations in snowpack melt on the Greenland ice sheet based on passive-microwave measurements. F. Glaciol., 41 (137), 51-60.

Serreze, M. C., J. A. Maslanik, J. R. Key, R. F. Kokaly and D. A. Robinson. 1995. Diagnosis of the record minimum in Arctic sea ice during 1990 and associated snow cover extremes. Geophys. Res. Lett., 22(16), 2183-2186.

Smith, D. M. 1998. Observation of perennial Arctic sea ice melt and freeze-up using passive microwave data. 7. Geophys. Res., 103 (C12), 27,753-27,769.

Thompson, D. W. J. and J. W. Wallace. 1998. The Arctic Oscillation signature in the wintertime geopotential height and temperature fields. Geophys. Res. Lett., 25(9), 1297-1300. 